\title{
CHARACTERISTICS OF THE NONGOVERNMENTAL SECTOR IN LATVIA
}

Kristaps ZDANOVSKIS, Faculty of Economics and Social Development, Latvia University of Agriculture, Svetes str. 18, Jelgava, LV-3001, Latvia, kristaps.zdanovskis@gmail.com

Nongovernmental organisations (NGOs) have played their role in political processesfor centuries, continuing to expand their activity and engage the public. The NGO sector in Latvia is young in comparison with Western countries. The first organisations emerged in Latvia after the country regainedthe second independence in the 1990s. The NGO sector in Latvia does not differ from that in other countries and has retaining its nature - any organisation is established voluntarily by a group of individuals with similar beliefs to advocate public interests at political level, for non-commercial purposes and with no government influence. Statistical data show the engagement of the public in NGO activities, which is promoted by progress in the world and such opportunities of the digital era as the Internet, mobile applications, social networks or e-platforms that can inform and mobilise the public fast for tackling some problem. As the NGO sector developed and its scope of activity expanded, new problems were identified, e.g. inability to establish a single system for the activity and financial transparency of organisations.

To exist in a long-term, NGOs need to adapt to a system. Organisations that have built up experience and made achievements represent future potential for new public activists in their work with public administration entities and decision-makers to meet the public's needs and in the interests of the public, thus, in cooperation, making a better and wealthier life for the country's residents.

The research aim is to analyse the NGO sector in Latvia. The research employed the following methods: monographic, descriptive, analysis and synthesis, as well as logical construction.

Keywords: civil society; history of NGOs; NGO classification.

\section{INTRODUCTION}

The ideas forming the nongovernmental sector came from the democratic West. In the period when the nongovernmental sector developed in the world, there was a communist regime in the Soviet Union, and the idea of development of the nongovernmental sector was not recognised there. After the collapse of the Soviet Union, nongovernmental sectors began emerging in the new independent countries, which were financially supported by the experienced Western countries, calling it the promotion of democracy and the formation of a civil society, while their real purpose was to shape the political environment towards the desired direction. Historically, an agenda of NGOs mainly involved problems related to human rights, peace and equality, by which they earned the attention of governments. The more governments began listening to NGOs and recognise their role in shaping civic dialogue, the more active the NGOs became and the more they expanded their activity. An essential factor affecting the number of organisations and the scope of their activity was overall progress in the world and globalisation (Davies, 2007). The development of technologies and infrastructures provided faster information exchange by means of telecommunications or air transport. Telecommunications considerably contributed to cross-border cooperation among NGOs, it was also promoted by international agreements made by governments and international financial organisations, e.g. the World Trade Organisation and the International Monetary Fund.

In parallel with the positive growth of organisations, there were problems that both emerged during the course of their work and were deliberately created by groups of individuals who used the idea of NGOs for dishonest purposes. Initially, the activity and idea of NGOs were based on ancient traditions, philanthropy and equal assistance for the entire society (Anheier, 2005). In the course of time and with the role of NGOs in political processes increasing, some groups of individuals began using the NGOs for their selfish purposes. This can explain the significant increase in the number of organisations and the expansion of their activity. This problem is very urgent in the fields where external financial assistance is available to NGOs. Ishkanian (2006) stresses that nowadays the beneficiary of NGO activity is not only the public but also governments that sometimes use the status of NGO as a cover. There are problems in the NGO sector in all countries, and it depends on every country's regulatory framework and efforts to enhance this sector. One of the key problems is the inability to provide the transparency of the sector because of the great number of NGOs being diverse in the scope of their activities. In Latvia too, approximately once in two years the association „Civic Alliance - Latvia”

Copyright (C) 2017 The Authors. Published by Aleksandras Stulginskis University. This is an open-access article distributed under the terms of the Creative Commons Attribution License (CC-BY 4.0), which permits unrestricted use, distribution, and reproduction in any medium, provided the original author and source are credited. 
produces a report on the NGO sector in Latvia, which includes statistical data, amendments to legal acts and analyses of the performance and financial data of the NGOs, population engagement etc. Such reports are a striking example of imperfections in assessing the sector, as official statistical data are used minimally, while the information is acquired individually by surveying and analysing the NGOs. The media often analyse the NGO sector's problems, encouraging responsible institutions to find solutions, yet the solutions are not implemented or their implementation is postponed (Defacto, 2013).

Several positive trends are observed regardingthe enhancement of the NGO sector in Latvia, as associations and foundations are classified as different from political parties, religious organisations etc., the rules for classifying the associations and foundations were introduced and the work on establishing a Latvian NGO Fund, the purpose of which is to control the allocation, use and accounting of NGO government funding. Therefore, the research aim is to analyse the NGO sector in Latvia.

To achieve the aim, the following specific research tasks were set:

1. To describe the historical background of NGOs in the world.

2. To analyse the quantitative indicators of the NGO sector in Latvia.

3. To identify problems in the NGO sector in Latvia.

\section{MATERIALS AND METHODS}

The research used research papers related to the present topic and information provided by the Central Statistical bureau of Latvia (CSB), Lursoft, national institutions and ministries on their websites. The research employed the following methods: monographic, descriptive, analysis and synthesis, as well as logical construction.

\section{DISCUSSION AND RESULTS}

\section{Historical background of NGOs}

A non-governmental organization (NGO) is any non-profit, voluntary citizens' group, which is organized on a local, national or international level. Task-oriented and driven by people with a common interest, NGOs perform a variety of service and humanitarian functions, bring citizen concerns to governments, advocate and monitor policies and encourage political participation through provision of information (Definition..., [s.a.]). Bibliographical sources have no accurate information on the origins of NGOs. Researcher Lewis D. (2009) points out that the term NGO is a phenomenon of the $20^{\text {th }}$ century, and groups of individuals with similar interests, the activity of which could be attributed to the functions of NGOs, existed for centuries. The historical evolution of NGOs is accurately described by Charnovitz (1997), dividing it into seven periods. However, the authors believe that the historical evolution of NGO may be divided into three periods: before World War I; after World War II and the period since 1992 (Figure 1).

The origins of the first known NGOs date back to the $18^{\text {th }}$ century in the United States of America and Western Europe in relation to tackling the problem of protection of human rights, e.g. the abolishment of slave trade, the free movement of individuals, equality etc. As NGOs developed, at the end of the $19^{\text {th }}$ century they focused on infrastructure development problems, intellectual property rights, drug control, agricultural development etc. However, the world wars ruined what was achieved by NGOs, placing them at the start position aimed at helping war victims and children who lost their parents and securing peace in the world.

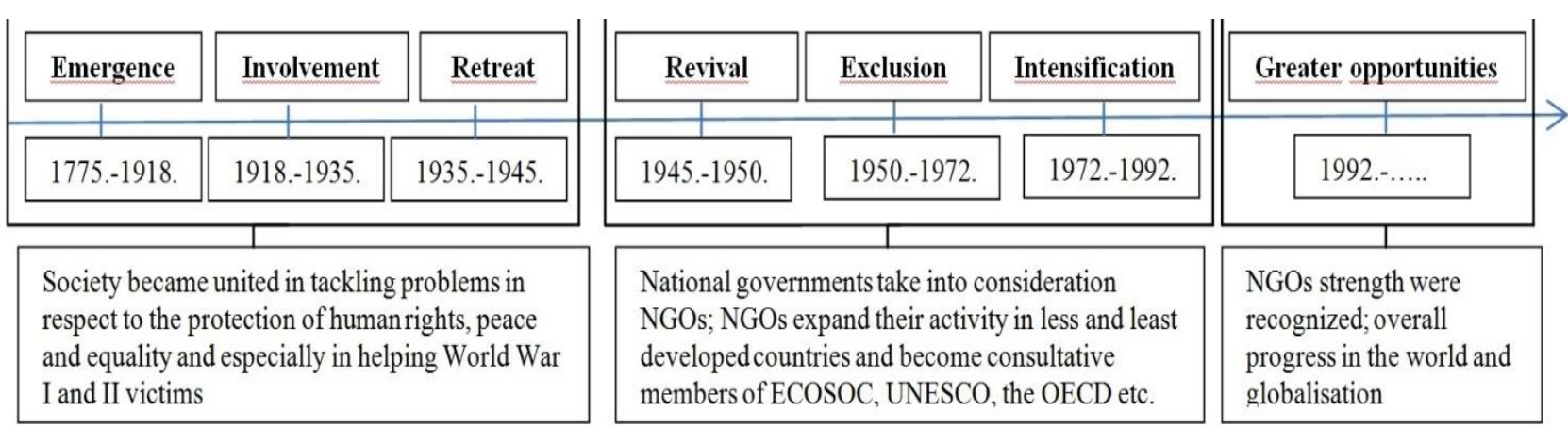

Source: authors' construction based on Charnovitz, 1997

Figure 1. Seven (three) key historical evolution periodsof nongovernmental organisations in Western countries from 1775 to 1992

After World War I, the League of Nations established in 1920 became the leading organisation, the key objectives of which in global context involved ensuring peace and solving conflicts through diplomatic negotiations as well as improving life conditions for the population. The League of Nations was the first organisation whose opinions were taken into consideration by national governments, and some bibliographical sources state that it was the initiator of NGO history. The League of Nations united its members from 58 countries, advocated the interests of society and entrepreneurs and, for the first time, established today well-known trilateral relations: government - business - society (Lewis D., 2014).

Political tension in Europe before World War II was stronger than the efforts of NGOs in ensuring peace, and after 1935 this organisation began gradually losing its influence and the political tension resulted in World War II. Before World War II, the League of Nations fully lost its role in tackling international relations. 
In 1945, the United Nations Organisation (UN) was founded as the successor of the League of Nations to tackle problems caused by World War II; its statute (Article 71 of Chapter 10) stipulates that the UN'sEconomic and Social Council(ECOSOC) can consult with nongovernmental organisations that deal with the matters being within the competence of the UN, recognising the essential role of NGOs in sustainable development. In this way, the acronym NGO got its official status and significance, which was referred to in some bibliographical sources as the beginning of NGO history. Following the example of the UN, NGOs began cooperating with UNESCO and the World Trade Organisation as well. Expanding their aid activities in less and least developed countries in Africa and Asia, NGOs were regarded as a more trustful and less corrupted partner in development matters than any government (Berthoud O. 2001). This recognition, overall progress in the world and globalisation at the end of the $20^{\text {th }}$ century were a historic turning point when NGOs realised their strength; there was a boom in their number in various sectors, not only in Western countries but also in the whole world. A particularly great increase in the number of NGOs was observed in East European countries and the countries of the former Soviet Union, including Latvia.

\section{Characteristics of the NGO sector in Latvia}

Just like in other world countries, in Latvia too NGOs are registeredas operating in various areas: environmental protection, agriculture, social services, culture etc. In Latvia, the first NGOs were founded after the collapse of the Soviet Union, shifting from the socialism system to the democratic one. Historically, this period is consistent with what was stated by Charnovitz (1997) that the number of organisations considerably increased in the early 1990s, particularly in Eastern Europe and the countries of the former Soviet Union.

Unlike other countries, in Latvia all nongovernmental sector organisations are denoted by one acronym - NGO, and public organisations, regardless of their kind of activity, are divided into two groups:

- $\quad$ avoluntary union of persons founded to achieve the goal specified in the statute of the association, which does not have a profit-making nature;

- a foundation, also a fund, is an aggregate of property that has been set aside for the achievement of a goal specified by the founder, which shall not have a profit-making nature (Associations and..., 2003).

In Latvia, in addition to the status of NGO, organisations may be granted the status of public benefit organisation that is aimed at promoting the public benefit activities of associations and foundations, as well as religious organisations and the institutions thereof, granting tax relief and other kinds of support to the organisations (Public Benefit..., 2004).

It is not possible to know how many NGOs exist in the world or EU zone. The number is very high, dividing those in two categories - international and national level organizations. Most of the all NGOs are national level. It making difficult to make a comparative analyze between states, because in each state is other system of classification and definition, and today the activity of NGOs are expanded on a very large scale. Is possible to get the number of registered organizations, but to get reliable information about active organization, it is additional research in each state.

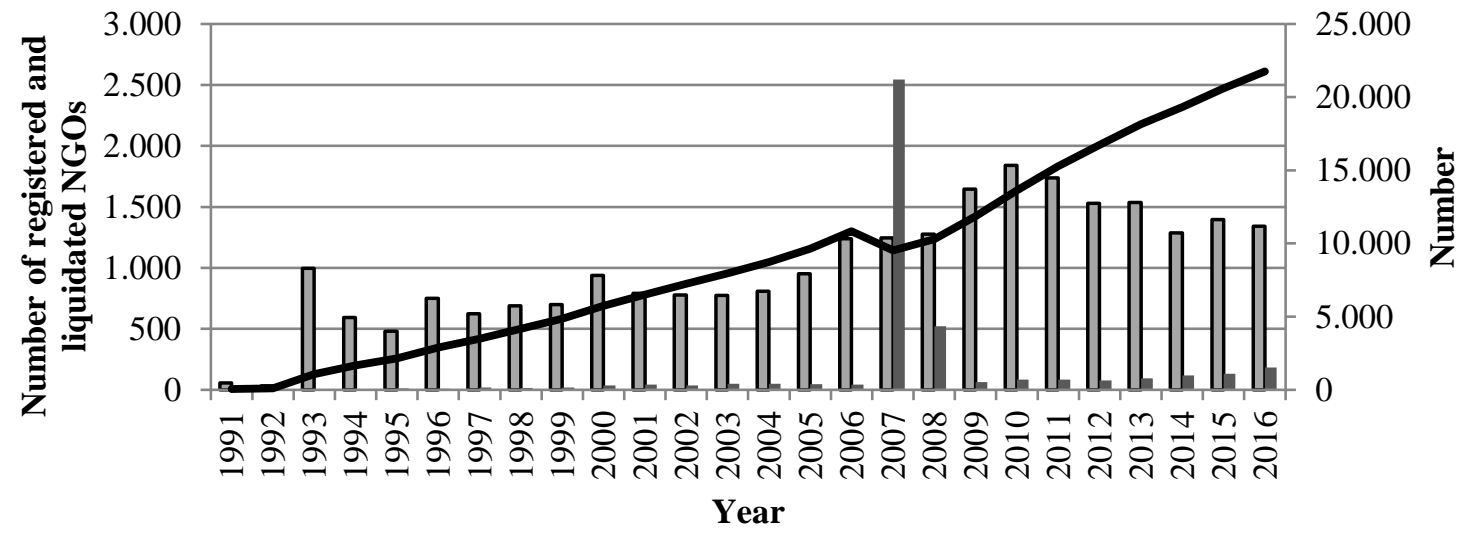

$\square$ Registered $\quad$ Liquidated $\longrightarrow$ Number of NGOs

Source: authors' construction based onLursoft data, 2017

Figure 2. Changes in the number of NGOs in Latvia in the period 1991-2016

In the first years of independence, 89 organisations were founded in Latvia, while in 1993 already as many as 996 organisations were established. The number of newly established tended to increase year by year. On average, 988 organisations were founded in Latvia in the period 1991-2016. However, in the first two months of 2017, 188 organisations were founded, which was, on average, 4.5 organisations per working day. At the beginning of 2017, there were 21756 NGOs in Latvia (Lursoft..., 2017). In Latvia, 80\% of the total NGOs were founded after 2004. The fast increase in the number of NGOs was affected by a number of interrelated factors:

- on 1 January 2005, such a form of business organisation as non-profit limited liability company was liquidated in Latvia; consequently, a portion of the organisations were reregistered as associations or foundations;

- availability of EU funding for various NGO activities. Individuals had to register an association in order to submit an EU co-funded project, while the Rural Development Programme LEADER's support activity specified 
certain territories for municipalities, and NGOs had to establish a joint organisation;

- coalitions of various NGOs and cooperation platforms emerged, thus increasing the capacity of the organisations in a certain field and their ability to get involved in dialogue with policy makers;

- $\quad$ establishment of NGOs in some fields, e.g. social services, was motivated by the economic recession and the insufficient supply of the services by the central or local government;

- real estate development and an opportunity to acquire EU funding for the renovation of residential housing;

- various interest or leisure time spending groups registered an association to settle contractual and financial obligations to public or private service providers (NGO News, 2015).

All the registered organisations were not active, and annually, on average, $5 \%$ of their total wereliquidated, reaching the greatest number in 2007 and 2008 when 3067 organisations were liquidated owing to amendments to the legislation. Initially, the activity of organisations was regulated by the law of 15 December 1992 "On Public Organisations and Associations Thereof”, which did not classify nongovernmental sector organisations as different from such public associations as trade unions, political parties etc. After joining the EU, Latvia had to tackle the problem of nongovernmental organisations, and therefore it was decided to make a separate Associations and Foundations Law, which came into force on 1 April 2004, in order to precisely define the activity of NGOs and in order that the law does not overlap with other laws regulating the activity of public organisations. Transition to the new law was stipulated by the Law on the Procedure for the Coming into Force of the Associations and Foundations Law, Section 9 of which provided that public organisations registered in the Register of Public Organisations before 31 December 2005 had to be reregistered in the Register of Associations and Foundations that was administered by the Register of Enterprises (RoE) of the Republic of Latvia (LV) (Saeima, 2004). To be more precise, associations and foundations that were not reregistered were liquidated by the RoE, which explains the great number of liquidated organisations in 2007 and 2008 . The registration had to be done by organisations themselves, and the number of liquidated organisations indicated that approximately $25 \%$ of NGOs were registered but were not active. However, the liquidation of organisations in the other years may be explained by the expansion of their activity, a shift to another legal form, the establishment of an NGO for implementing a particular activity, the loss of influence etc. (Lursoft..., 2017).

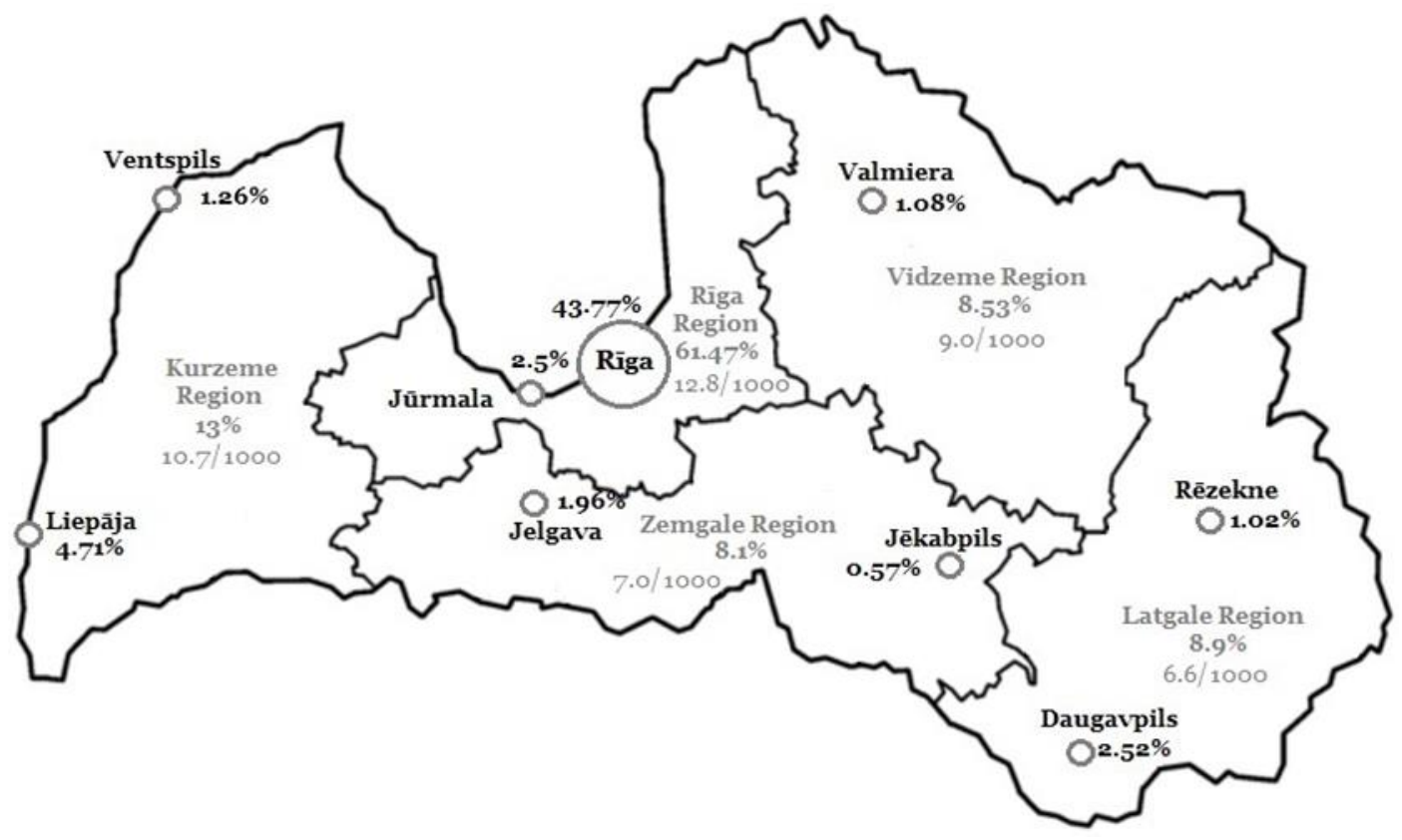

Source: authors' construction based on Lursoft data, 2017

Figure 3.Percentage distribution of public organisations, their associations and foundations by city and by region in Latvia; organisation density per 1000 capita in the regions of Latvia in 2016

Both Lewis (2009) and Civic Alliance..., (2016) point out that an essential indicator is the number and density of NGOs in the country's regions. The greatest number of registered organisations is still reported in Riga region with 21756 NGOs or $61.47 \%$ of the total. A comparison of the numbers of organisations in Latvia's cities reveals that $43.77 \%$ of the total number of NGOs registered in Latvia are located in Riga, while 59.38\% are situated in nine largest cities. The uneven distribution of NGOs across the regions may be explained by differences in the density of population, the activity of residents, the development level of a region, business opportunities etc. Such a situation indicates disparities in the defence of interests of residents across the country's regions. NGO support centres are located in every municipality and city of Latvia; the centres provide assistance to active residents, informal groups of residents and registered organisations to commence and expand their activity, to attract funding and to do routine work (KNVOAC, [s.a.]). Such NGO centre activities are free of charge, as they are funded through various projects and charity. The centres have the status of public benefit organisation, which entitles benefactors to tax relief (DNVOAC, 2009).

Another essential factor is the number of organisations per 1000 capita or civic participation at national and 
regional level, which helps build a stable link between the individual and the State, contributing to the responsibility of individuals for the society where they live in. Civic participation involves a wide spectrum of activity: participation in elections, political organisations, trade unions, NGOs, associations etc. A study done by Latvian Facts (2013) showed thatonly $16.5 \%$ of the surveyed residents believed that they could influence governmental decision-making in Latvia, while the Ministry of Culture explained that this was one of the most essential reasons for the insufficient civic participation of the population. In the Guidelines for National Identity, Civic Society and Integration Policies for $2012-$ 2018, the Ministry of Culture has stated that nongovernmental organisations in Latvia are not financially and administratively strong and sustainable. To achieve the targets set by the Ministry of Culture in relation to broader civic participation, the average number of NGOs per 1000 capita in Latvia has to increase to 9 in 2018, which could be achieved if holding informative campaigns at least once a year (Civic Alliance..., 2016). This indicator was exceeded already in 2015 when there were 10.5 organisations per 1000 capita in Latvia. Figure 3 shows that the target was reached at regional level, except for the regions of Zemgale and Latgale.

Initially, all associations advocating the interests of residents were defined as public organisations, regardless of whether they were NGOs or political parties. Since one law does not fit all public organisations, separate laws were made in order to regulate the activity of every kind of organisation. Of the total number of public organisations registered in the country, the majority or $78.6 \%$ were comprised of associations, $5.8 \%$ were foundations, $0.9 \%$ were trade unions, $0.3 \%$ were political parties and $14.4 \%$ were other organisations such as corporations, unions, political organisations etc.

Like in other countries, in Latvia too, a problem emerged to classify organisations after the large increase in their number and the expansion of their scope of activity, which does not allow acquiring comprehensive qualitative and quantitative information about developments in the sector.

Researchers Salamon and Anheier (1992) and Lewis (2014) point out that historically, when organisations were engaged only in tackling social assistance problems, the situation was much simpler; however, with the scope of their activity expanding to other fields, such as culture, agriculture, politics etc., there is no single approach in the world that would allow classifying all organisations, as any organisation can be engaged in a number of fields - they are different in size and scope, thefield of their activity is diverse as well as the models developed are not adaptive to changes in the activity of the organisations. An essential problem of classification is the real goal of activity of an organisation. Researcher Ishkanian (2006) points out that the real goal of activity of organisations can be most influenced by the financial assistance of external donors; in this situation, according to her, organisations may be classified as "real" NGOs, "donation eaters" or corruptive organisations that acquire funds in an unfair way and "pocket" NGOs or organisations actually belonging to the government.

The main problem of classification in Latvia is the fact that every institution classifies NGOs according to the information it requires and processes. The RoE classifies organisations according to the EU Statistical classification of economic activities or NACE (LIAA, [s.a.]). In the period when the NACE 1.1 classification was effective, organisations were included insection O "Public, social and individual services", yet in 2006 when NACE Rev.2 became effective, organisations were moved to section S "Other services" despite the fact that the NACE classification encompassed all the fields of business. When registering an NGO, its field of activity is specified where the goal of its activity, which often involves several fields of activity, is defined.

The Central Statistical Bureau of Latvia (CSB) collects information only about active organisations and considers only the fields of activity specified in their annual reports by using the NACE classification. According to the CSB data, there were 11112 active organisations, accounting for 53.9\% of the total, in Latvia in 2015 (Figure 2.) (Central..., [s.a.]). The authors conclude that even though the CSB has reported the total number of active organisations, yet the categories of the NACE classification do not yield the expected result, as three largest categories are "Activities of public, political and other organisations", "Activities of organisations not elsewhere classified" and "Other services"; besides, the total number of organisations classified by NACE category is three times greater than the number of active organisations, which allows concluding that an organisation is engaged in at least three various fields of activity. Not a single classification method allows accurately identifying how many NGOs in Latvia advocate, for example, the interests of farmers. The CSBspecifies that there are 78 active organisations dealing with agriculture, forestry and fisheries, yet it has to be taken into account that a portion of the organisations focus on the matters of not only primary agricultural production but also agricultural processing and agricultural growth. There are also some organisations that perform NGO functions,but their legal form is a cooperative society. One of such organisations is Latvian pig breeding association

To contribute to the classification of NGOs, amendments to Paragraph 3 of Section 13 of the Associations and Foundations Law came into force on 2 January 2014 that provide that associations and foundations shall be classified according to their field of activity. LV Cabinet Regulation No. 779 "Classification of Associations and Foundations according to Their Field of Activity" came into force on 1 January 2016 (Cabinet..., 2013). The new regulation classifies the fields of activity of NGOs into 15 categories, such as culture and recreation, research and education, environmental and animal protection and other fields that are aligned with the NACE Rev. 2 classification. NGO activities having no NACE code are included in class 94.99 Activities of other membership organisations not elsewhere classified, which are subclassified and provided with explanatory notes, thereby giving an opportunity to classify NGOs into another 20 categories, which is not possible by means of NACE codes. However, the authors believe that the new classification regulationis not comprehensive because, for example, it is not clear which section agricultural organisations belong to. The number of such organisations, according to the CSB, is insignificant, yet they advocate the interests of the majority of farmers in Latvia. On the one hand, these organisations might be included into category 7 - environmental and animal protection -, yet this section better represents NGOs of environmental activists, while category 9 - the rule of law and advocacy - is too general. 
The authors stress the problem of classification for financial reasons, as NGOs in Latvia, to a great extent, are funded by the government, and it funds agricultural NGOs most generously. In 2017, the Ministry of Agriculture (MoA) decided to allocate EUR 701920 to agricultural NGOs for their daily operation, activities of popularisation of the agricultural industry, international business trips, participation fees at international organisations etc. The largest share of the funding was given to nine organisations of the Advisory Council of the MoA, for example, for their daily expenses, totally granting EUR 188839 or, on average, EUR 21 thou. per organisation (Rules about..., 2013). The organisations of the Advisory Council receive funding every year and are certain that it is going to be grantedon a non-competitive basis or with no public procurement procedure carried out.However, small producer organisations submit their plans of activities and cost estimates to the MoA in the autumn of every year, and the MoA makes a decision on the size of financial assistance after assessing the importance of their activities. In Latvia, all the ministries give financial assistance to NGOs, and the key problem is how to control how effectively the funding is spent. There is no methodology developed in the country regardingmeasuringthe effectiveness of financial assistance. The diversity of organisations and the engagement of the organisations in several fields of activity do not allow establishing a single control system. The authors have already pointed out that the statistical data indicated the engagement of organisations in a number of fields of activity, and it is understandable that the organisations indirectly used the funding granted for the purposes other than those for which they were granted when performing their daily activities in various fields. The lack of state control over financial assistance discredits the NGO sector in the eyes of taxpayers. The opinion of Ishkanian (2006) on the real nature of organisations funded by external sources was stated above, while Lewis D. (2014) points out that the term NGO has become unpopular in some countries because the organisations have been implicated in corruptive activities. To tackle the situation in Latvia, the government continues working on the law "On the Establishment of a Government-funded NGO Fund" in order to have the legalbasis for the transparent allocation of funding to NGOs, the build-up of their capacity and support for their main activities. The government has defined the development and sustainability of NGOs as a priority, which isaimed at enhancing residents' civic participation skills and giving them opportunities to engage in tackling common problems (Civic Alliance..., 2016).

\section{CONCLUSIONS}

1. Nongovernmental organisations are one of the most ancient forms of consolidation in a civic society, which strengthened its political influence before the acronym NGO was officially recognised by national governments and preserved its nature as a voluntary union of individuals sharing the same ideas to advocate public interests at political level, for non-commercial purposes and at national and international level.

2. Nowadays, there is competition among the leading NGOs of an industry, and reachability and accurate information sent to their members, which, in the digital era, is possible by means of the Internet, mobile communications, social networks etc., play an important role in the activity of an organisation in a long-term.

3. Even though the NGO sector is relatively young in Latvia, the number of organisations considerably increased annually after regaining the second independence in 1991, reaching 21756 organisations in 2017. According to the data of the Central Statistical Bureau of Latvia, only 11112 organisations or $53.9 \%$ of their total were active. The fact that all the organisations that were not liquidated were not active was confirmed the large number of organisations, which were not reregistered by their owners with the new Register of Associations and Foundations, liquidated by the Register of Enterprises in 2007 and 2008.

4. Like in other countries, in Latvia too the NGO sector has a lot of problems such as the classification of organisations, transparency of their financial flows, the procedure of granting financial assistance by the government, measurement of the effectiveness of financial assistance granted etc. The reports produced by the association „Civic Alliance - Latvia” on the NGO sector repeatedly address the same problems, raising a question why no solutions are implemented after ideas have been expressed and who are the real beneficiaries in the NGO sector.

\section{REFERENCES}

1. Anheier, H.K. 2005. Nonprofit Organizations: Theory, Management, Policy. London: Routledge.

2. Associations and Foundations Law. 2004. Saeima of the Republic of Latvia. Available at https://likumi.lv/doc.php?id=81050 (Accessed on 14/08/2017).

3. Berthoud, O. 2001. NGOs: Somewhere Between Compassion, Profitability and Solidarity. Available at: http://www.envio.org.ni/articulo/1526 . (Accessed on 03/08/2017).

4. Cabinet of Ministers. 2013. Rules about institutional sector classification. Available at https://likumi.lv/doc.php?id=263203 (Accessed on 03/08/2017).

5. Central Statistical Bureau [s.a.] Economically active enterprises by main kind of activity (NACE Rev. 2). Available at http://data.csb.gov.lv/pxweb/lv/uzreg/uzreg_ikgad_01_skaits/SRG0201.px/?rxid=cdcb978c-22b0-416a-aacc (Accessed on 03/08/2017)

6. Charnovitz, S. 1997. Two centuries of participation: NGOs and international governance'. Michigan Journal of International Lawm, Vol. 18. pp. 183-286.

7. Civic Alliance - Latvia. 2016. Report about NGO sector in Latvia 2015. Available at http://nvo.lv/site/attachments/29/04/2016/NVO_PARSKATS-2015-23.04.pdf (Accessed on 10/08/2017). 
8. Davies T. R. 2007. The Possibilities of Transnational Activism: the Campaign for Disarmament between the Two World Wars. Boston: Brill.

9. DeFacto. 2013. ZM dāsni uztur lauksaimnieku NVO. http://www.lsm.lv/lv/raksts/latvija/zinas/zm-dasni-uztur-lauksaimniekunvo.a59097/ (Accessed on 12/08/2017).

10. Definition of NGOs [s.a.] NGO Global Network. Available at http://www.ngo.org/ngoinfo/define.html (Accessed on 09/08/2017).

11. DNVOAC. 2009. Dienvidlatgales NVO atbalsta centrs. http://www.nvoc.lv/index.php?show=46 (Accessed on 10/08/2017).

12. Ishkanian, A. 2006. 'From "velvet" to "colour" revolutions: Armenian NGOs' participation in the poverty reduction strategy paper (PRSP) process'. Journal of International Development, Vol. 18, No. 5, pp. 729-740. https://doi.org/10.1002/jid.1301

13. KNVOAC [s.a.] Kurzemes NVO atbalsta centrs. http://www.kurzemesnvo.lv/index.php/kas-mes-esam2/knvoac-darbiba (Accessed on 10/08/2017)

14. Latvian Facts. 2013. The society opinion about NGO sector in Latvia. Available at http://www.nvo.lv/site/attachments/03/11/2014/Iedzivotaju_aptauja.pdf (Accessed on 03/08/2017).

15. Lewis D. 2009. Nongovernmental Organizations, Definition and History. International Encyclopaedia of Civil Society. London School of Economics and Political Science, UK 2010. pp 1056-1062.

16. Lewis D. 2014. Non-Governmental Organizations Managament and Development (Third Edution). United Kingdom: Routledge.

17. LIAA. [s.a.] Statistical classification of economic activities NACE. Available at: http://www.liaa.gov.lv/lv/es-fondi/noderigainformacija/saimniecisko-darbibu-statistiska-klasifikacija-nace-2-red (accessed on 11/08/2017).

18. Lursoft Statistic. 2017. Associations, Foundations and Public Organisation. Available at https://www.lursoft.lv/lursoft_statistika/?\&id=41. (Accessed on 10/08/2017). [In Latvian]

19. NGO news. 2015. Since joining EU risen sharply the number of NGO. Available at http://www.zkcentrs.lv/2015/08/17/kops-iestasanas-esstrauji-audzis-nevalstisko-organizaciju-skaits/ (Accessed on 11/08/2017).

20. Public Benefit Organisation Law. 2004. Saeima of the Republic of Latvia. Available at https://likumi.lv/doc.php?id=90822 (Accessed on 14/08/2017)

21. Rules about state support for agriculture. 2013. Rules of Cabinet of Ministers of the Republic of Latvia. Available at https://likumi.lv/doc.php?id=263434 (Accessed on 14/08/2017).

22. Saeima. 2004. Law of the entry in force the law of Associations and Foundations. https://likumi.lv/doc.php?id=83922 (Accessed on 14/08/2017).

23. Salamon, L., Anheier, H. 1992. In search of the non-profit sector: The question of definitions. Voluntas: International Journal of Voluntary and Nonprofit Organizations, Vol. 3, Iss. 2, pp 125-151. https://doi.org/10.1007/BF01397770 